\title{
Stresli Durumlarda Bilişsel Kontrol ve Bilișsel Esneklik: Bir Ölçek Uyarlama Çalışması
}

\section{Cognitive Control and Cognitive Flexibility in the Context of Stress: A Scale Adaptation}

Ayşe Sibel Demirtaş ${ }^{1}$ (i)

${ }^{1}$ Dr. Öğr. Üyesi, Alanya Alaaddin Keykubat Üniversitesi, Eğitim Fakültesi, Rehberlik ve Psikolojik Danışmanlık Anabilim Dalı, Antalya, Türkiye

\section{ORCID: A.S.D. 0000-0001-7793-9583}

Sorumlu yazar/Corresponding author: Ayşe Sibel Demirtaş,

Alanya Alaaddin Keykubat Üniversitesi, Eğitim Fakültesi, Rehberlik ve Psikolojik Danışmanlık Anabilim Dalı, Antalya, Türkiye E-posta/E-mail: sibel.demirtas@alanya.edu.tr

Başvuru/Submitted: 22.03.2019 Revizyon Talebi/Revision Requested: 28.03.2019

Son Revizyon/Last Revision Received: 24.07.2019

Kabul/Accepted: 02.08.2019

Online Yayın/Published Online: 05.12.2019

Atıf/Citation: Demirtas, A. S. (2019). Stresli durumlarda bilişsel kontrol ve bilişsel esneklik: Bir ölçek uyarlama çalışması. Psikoloji Çalışmaları - Studies in Psychology, 39(2): 345-368.

https://doi.org/10.26650/SP2019-0028

\begin{abstract}
öz
Bu çalışmada, stresli durumlarda bireylerin duygular üzerinde bilişsel kontrol ile değerlendirme ve başa çıkma esnekliğini ölçme amacı taşıyan Bilişsel Kontrol ve Esneklik Ölçeği'nin (The Cognitive Control and Flexibility Questionnaire; Gabrys, Tabri, Anisman ve Matheson, 2018) Türkçe'ye uyarlanması amaçlanmıştır. Ölçeğin psikometrik özellikleri, katılımcılarının üniversite öğrencileri olduğu üç farklı aşama ile sınanmıştır. Araştırma, ölçüm aracının dilsel eş değerliğini sınamayı amaçlayan birinci aşamada 47 (\%66 kadın, \%34 erkek), ölçüm aracının yapı geçerliğini ve güvenirliğini sınamayı amaçlayan ikinci aşamada 241 (\%65 kadın, \%35 erkek), ölçüm aracının diğer yapılarla ilişkilerinin, iç tutarlılığının, madde geçerliğinin ve güvenirlik değerlerinin incelenmesini amaçlayan üçüncü aşamada 352 (\%45 kadın, \%55 erkek) olmak üzere toplam 640 katılımcı ile gerçekleştirilmiştir. Ölçüm aracının özellikleri dilsel eşdeğerlik, madde analizi, yapı geçerliği ve Cronbach Alpha güvenirlik sınama yöntemleriyle incelenmiştir. Ölçeğin geçerlik sınamaları için katılımcılara Bilişsel Esneklik Envanteri, Sürekli Umut Ölçeği ve Algılanan Stres Ölçeği uygulanmıştır. Yapı geçerliği için gerçekleştirilen doğrulayıcı faktör analizi bulguları ölçeğin Duygular Üzerinde Bilişsel Kontrol ile Değerlendirme ve Başa Çıkma Esnekliği olmak üzere iki faktörlü yapısının yeterli uyum değerlerine sahip olduğunu göstermiştir. Ayrıca beklenildiği gibi, Bilişsel Kontrol ve Esneklik Ölçeği, bilişsel esneklik ve sürekli umut ile pozitif, algılanan stres ile ise negatif yönde anlaml i ilişkiler göstermektedir. İkinci ve üçüncü aşama kapsamında alt faktörler ve ölçeğin tümü için hesaplanan Cronbach Alpha güvenirlik katsayıları .85 ile .91 arasında değişmektedir. Sonuç olarak araştırma bulguları ölçeğin Türk üniversite öğrencilerinin stresli durumlarda duygular üzerinde bilişsel kontrol ile değerlendirme ve başa çıkma esnekliği düzeylerini değerlendirmede kullanılabilecek geçerli ve güvenilir bir ölçüm aracı olduğuna ilişkin destek sunmaktadır.
\end{abstract}

Anahtar Kelimeler: Bilişsel kontrol, bilişsel esneklik, ölçek uyarlama, geçerlik, güvenirlik 


\section{ABSTRACT}

The purpose of the current research study is to adapt The Cognitive Control and Flexibility Questionnaire (CCFQ; Gabrys, Tabri, Anisman, \& Matheson, 2018), which aims to measure the levels of cognitive control over emotions, appraisal and coping flexibility of individuals, into Turkish. The psychometric properties of the scale were tested in three stages in which the participants were university students. The first stage of the research, aimed to test the linguistic equivalence of the instrument, was conducted with 47 participants ( $66 \%$ female, $34 \%$ male), the second stage, aimed to test the construct validity and reliability of the measuring instrument, was conducted with 241 participants $(65 \%$ female, $35 \%$ male), the third stage, aimed at examining the relationship of the measuring instrument with other structures, internal consistency, substance validity and reliability values, was conducted with 352 participants $(45 \%$ female, $55 \%$ male). The psychometric properties of the scale were investigated by linguistic equivalence, item analysis, construct validity and Cronbach's alpha reliability. The Cognitive Flexibility Inventory, The Dispositional Hope Scale and The Perceived Stress Scale were used to test the validity. The results of the confirmatory factor analysis showed that the two-factor structure of the scale, Cognitive Control over Emotion and Appraisal and Coping Flexibility, has adequate fit values. As expected, it was found that the scale has positive and significant relationships with cognitive flexibility and dispositional hope, and negative and significant relationship with perceived stress. In the second and the third phases of the study, Cronbach's Alpha reliability coefficients were found to range from .85 to .91 . In conclusion, the research findings indicate that the Turkish Form of CCFQ is a valid and reliable tool for the measurement of cognitive control over emotion and appraisal, and the coping flexibility of the Turkish university students in the context of stress.

Keywords: Cognitive control, cognitive flexibility, scale adaptation, validity, reliability

\section{EXTENDED ABSTRACT}

Cognitive control and cognitive flexibility is an essential feature in the ability of an individual to adjust to changing environments and to play a role in goal-oriented behavior (Gabrys, Tabri, Anisman, \& Matheson 2018). Cognitive flexibility is associated with the individuals' capability to adjust the problem solving plan, in compliance with the requirements of the task (Al Jabari, 2012). Cognitive flexibility is linked with multiple thinking strategies and the use of mental frameworks. Cognitively flexible people have capabilities to explore the environment to define emerging changes and generate multiple strategies to be ready (Gurvis \& Calarco, 2007). Although there is no consensus within the literature about the definition and measurement of this construct, the core component of cognitive flexibility is "the ability to switch cognitive sets to adapt to the changing environmental stimuli" in most operational definitions (Dennis \& Vander Wal, 2010, p. 242). Cognitive control refers to the ability to block non-relevant information while focusing on information that is currently inappropriate for a particular purpose (Gabrys et al., 2018). The cognitive control defines the ability to define, manage, and process the information in an effective and adaptive manner, in order to direct the behavior to the individual's internal goals (Badre, 2011), and depends on the multiple executive functions, including working memory, blocking, conflict monitoring, and setting change (Gläscher et al., 2012; Mackie, Van Dam, \& Fan, 2013). Studies reported on the context of stressful experiences examined 
cognitive control and flexibility, emotional regulation, and processes related to depressive symptoms. However, it is not fully understood how these capabilities can be expressed in stressful situations (Gabrys et al., 2018). In this respect, Gabrys et al. (2018) have suggested that cognitive control and flexibility can be demonstrated through a variety of key processes such as attention, assessment / reassessment and approval of specific coping strategies, and have developed the Cognitive Control and Flexibility Questionnaire (CCFQ). The purpose of the current research study is to adapt the Cognitive Control and Flexibility Questionnaire, which was designed to measure cognitive flexibility and control levels of individuals in stressful situations, into Turkish.

\section{Method}

The validity and reliability testing study of the scale was conducted with three different study phases. The research was conducted on 47 participants (\% 66 female, $\% 34$ male) for the first phase of the study, 241 participants (\% 65 female, $\% 35$ male) for the second phase of the study and 352 participants (\%45 female, \%55 male) for the third phase of the study, for a total of 640 participants. The psychometric properties of the scale were investigated by linguistic equivalence, item analysis, construct validity (convergent validity, relationships with other constructs, internal consistency) and Cronbach's alpha reliability testing methods. The Cognitive Flexibility Inventory (Dennis \& Vander Wal, 2010), Dispositional Hope Scale (Snyder et al., 1991) and the Perceived Stress Scale (Cohen, Kamarck, \& Mermelstein, 1983) were also used for testing the validity.

\section{Results}

In the first phase of the study, the test-retest correlation over two weeks for the linguistic equivalence of the scale was found to be high (appraisal and coping flexibility: $r(45)=.88$, $p<.01$; cognitive control over emotion: $r(45)=.96, p<.01$; total scale: $r(45)=.95, p<.01)$. The results of the confirmatory factor analysis for the construct validity demonstrated that all $t$ values were significant, and the two-factor model, as in its original form, had acceptable fit indexes $\left(X^{2} / s d=2.63, \mathrm{NFI}=.94, \mathrm{CFI}=.96, \mathrm{GFI}=.86, \mathrm{AGFI}=.82, \mathrm{IFI}=.96, \mathrm{SRMR}\right.$ $=.07$ ve RMSEA $=.08)$. The findings of the Pearson correlation analysis showed that the Turkish form of CCFQ was positively correlated with the Cognitive Flexibility Inventory and Dispositional Hope Scale, and negatively correlated with the Perceived Stress Scale. Cronbach's alpha internal consistency coefficient was found as .88 for Cognitive Control over Emotion factor, .88 for the Appraisal and Coping Flexibility factor, and .90 for total scale on the second study and as $.85, .91$ and .91 , respectively, on the third phase of the study. 


\section{Discussion}

In conclusion, the research findings present evidence that the Turkish form of CCFQ is a valid and reliable measurement tool that can be used to measure the cognitive flexibility of Turkish university students in the context of stress. The measurement tool can be applied in experimental and correlational studies in different fields of psychology by researchers, as well as in determining the cognitive flexibility levels of individuals by the practitioners. As the sample group of this study is composed of university students, it would be useful to test the scale with the other groups to determine the validity of the scale. As the scale is short and easy to implement, it is thought that it will support further research to be done about cognitive control and flexibility. 
Yaşamları boyunca bireyler öngörülemez, kontrol edilemez veya aşırı yüklenme olarak değerlendirdikleri yaşam olayları karşısında stres algılarlar (Cohen, Kamarck ve Mermelstein, 1983). Bireylerin zihinsel, duygusal, fiziksel, ruhsal ve sosyal ortamları değiştikçe, yaşam değişimin getirdiği stresle başa çıkabilmeyi gerektirir (Coleman, 1993). Bireyler uyum ya da değişim talepleriyle karşı karşıya kaldıklarında, sahip oldukları kaynaklarını, başa çıkma becerilerini ve çevrenin taleplerine cevap verebilme becerilerini bilişsel olarak değerlendirirler (Lazarus ve Folkman, 1984).

Bilişsel kontrol ve bilişsel esneklik, bireyin sürekli değişen ortamlara uyum sağlama becerisinde ve hedefe yönelik davranışlarında rol oynayan önemli bir özelliktir (Gabrys, Tabri, Anisman ve Matheson, 2018). Alan yazında bilişsel esnekliğin tanımı konusunda bir fikir birliği olmamasına rağmen, pek çok tanımda bilişsel esnekliğin temel bileşeni değişen çevresel uyaranlara uyum sağlamak için bilişsel yapıları değiştirme becerisi şeklindedir (Dennis ve Vander Wal, 2010). Martin ve Rubin (1995) bilişsel esnekliği, bireyin herhangi bir durumda seçenekler ve alternatiflerin mevcut olduğuna ilişkin farkındalığını, esnek olma ve duruma uyum sağlama istekliliğini ve esnek olma konusunda öz-yetkinliğini kapsayan bir kavram olarak tanımlamışlardır. Bir başka tanıma göre bilişsel esneklik, değişen çevresel taleplere yanıt olarak hedefe yönelik davranışı uyarlayabilmedir (Garcia-Garcia, Barceló, Clemente ve Escera 2010).

Yurt içindeki ve yurt dışındaki ilgili alan yazın incelendiğinde, bilişsel esnekliğin nörobilişsel alanda (örn., Crowe, 1998; Tharp ve Pickering, 2011), eğitimde (örn., Alper ve Deryakulu, 2008; Cartwright, 2008) ve psikolojide (örn., Cousins, Tomlinson, Cohen ve McMurtry, 2016; Doğan-Laçin ve Yalçın, 2018) çalış1ldığg görülmektedir. Gabrys ve arkadaşlarına göre (2018) önceki çalışmalar bilişsel kontrol ve esneklik, duygu düzenleme ve depresif belirtilerle ilgili süreçleri incelemelerine rağmen bilişsel kontrol ve esneklik becerilerinin stresli durumlarda nasıl kullanılabileceği tam olarak anlaşılamamıştır. Bu bakımdan araştırmacılar bilişsel kontrol ve esnekliğin, dikkat, değerlendirme/ yeniden değerlendirme ve belirli başa çıkma stratejilerinin onaylanması gibi çeşitli temel süreçlerle ortaya konabileceğini önermişler ve Bilişsel Kontrol ve Esneklik Ölçeği’ni (BKEÖ) geliştirmişlerdir. Bu araştırmada, stresli durumlarda bireylerin bilişsel esneklik ve kontrol düzeylerini belirlemek amacıyla geliştirilen ölçüm aracının Türkçe’ye uyarlanarak yurt içi alan yazına kazandırılması amaçlanmıştır. Bu çalışma sayesinde ruh sağlığ́ alanında, bilişsel kontrol ve esneklik kavramlarına dikkat çekileceği düşünülmektedir. Bunun yanında Türkçe'ye uyarlanması amaçlanan ölçüm aracı, yalnızca stres- 
li durum bağlamında bilişsel esneklik ile ilgili yapılan araştırmalarda değil, aynı zamanda bireysel ve grupla psikolojik danışma uygulamalarında da kullanılabilecektir.

\section{Bilişsel Kontrol ve Bilişsel Esneklik}

Bilişsel bilim perspektifinden bilişsel esneklik, bilişsel kontrolün bir yönü veya sıralı olarak ya da paralel olarak çalışan çoklu bilişsel kontrol işlemleri olarak görülmüştür (Zaehringer, Falquez, Schubert, Nees ve Barnow, 2018). Bilişsel kontrol, konuyla ilgisi olmayan bilgiyi engellerken, durumla (veya amaçla) ilgili bilgilere dikkatin yönlendirilmesi olarak tanımlanabilir (Gabrys ve ark., 2018). Diğer bir ifade ile bilişsel kontrol, şu anda belirli bir amaç için uygun olan bilgilere odaklanırken konuyla ilgili olmayan bilgileri engelleme yeteneğini ifade eder (Morton, Ezekiel ve Wilk, 2011). Davranışı kişinin içsel hedeflerine yönlendirmek için ilgili bilgiyi etkin ve uyarlamalı olarak tanımlama, yönetme ve işleme yeteneğini tanımlayan bilişsel kontrol (Badre, 2011), çalışma belleği, engelleme, çatışma izleme ve ayar değiştirme dahil olmak üzere çoklu yürütme işlevlerine bağlıdır (Gläscher ve ark., 2012; Mackie, Van Dam ve Fan, 2013). Diğer araştırmacılar bilişsel esnekliği, bireylerin farklı görüşleri esnek yollarla düşünme ve ele alma derecesi olarak kavramsallaştırmışlardır (De Dreu, Baas ve Nijstad, 2008). Bilişsel esneklik bireyin problem çözme planını, görev değişikliğinin talepleri olarak ayarlayabilme becerisiyle ilgilidir (Al Jabari, 2012) ve değişen durumsal gerekliliklerin karmaşıklığına ve zorluk seviyesine bağlı olarak, bilginin birden fazla yolla yeniden yapılandırılması olarak ifade edilebilir (Jacobson ve Spiro, 1995). Bilişsel esneklik, farklı düşünme stratejileri ve zihinsel çerçeveler kullanma ile ilişkilidir. Bilişsel esnekliğe sahip bireyler, ortaya çıkan değişiklikleri tanımlama, durumlara yönelik kolektif bir anlayış geliştirme ve gelişebilecek her şeye hazırlıklı olma amacıyla çoklu stratejiler oluşturmak için çevreyi araştırma yeteneğine sahiptirler (Gurvis ve Calarco, 2007).

Önceki araştırmalar bilişsel esnekliğin, depresyon ve kaygı ile negatif yönde, psikolojik iyi oluş ile pozitif yönde ilişkili olduğunu göstermiştir (Cardom, 2016; Fu ve Chow, 2017; Kato, 2012). Bilişsel esnekliğin benlik saygısı ve fiziksel sağlık da dahil olmak üzere bireylerin iyi oluşu üzerinde olumlu etkiye, ruhsal sorunlar üzerinde ise olumsuz etkiye sahip olduğu gösterilmiştir (Koesten, Schrodt, ve Ford, 2009). Bilişsel kontrol ve esneklik, hedefe yönelik davranışları kolaylaştırmanın yanı sıra duygunun düzenlenmesinde yer almakta, bu becerilerin yoksunluğu ise ruh sağlığı ve kaygı bozukluklarında önemli rol oynamaktadır (Gabrys ve ark., 2018; Liao ve ark., 2019). Koster, Lissnyder, Derakshan ve De Raedt (2011) bozulmuş dikkat kontrolünün sürekli geviş getirme olarak tanımlanan 
ruminasyonla ilişkili olduğunu ve olumsuz etkiye yol açtığını saptamışlardır. Yapılan araştırmalar daha fazla bilişsel kontrolün, bireylerin endişe ve ruminasyonla başa çıkmalarına yardımcı olabileceğini göstermektedir (Robinson, Schmeichel ve Inzlicht, 2010).

$\mathrm{Bu}$ araştırmanın konusunu oluşturan Bilişsel Kontrol ve Esneklik Ölçeği (The Cognitive Control and Flexibility Questionnaire; Gabrys ve ark., 2018) bireylerin stresli durumlarda sahip olduğu bilişsel kontrol ve esneklik düzeylerini ölçmeyi amaçlamaktadır. Ölçek, bireyin araya giren, istenmeyen olumsuz içerikli düşünce ve duygular üzerindeki kontrol sağlama becerisini ve stresli bir durumla esnek bir şekilde başa çıkma becerisini ölçmektedir. Araştırmacılar ölçüm aracının geliştirilmesinde 3 farklı çalışma gerçekleştirmişlerdir. Araştırmacılar ilk çalışma sonucunda ölçüm aracının duygular üzerinde bilişsel kontrol ile değerlendirme ve başa çıkma esnekliği olmak üzere istikrarlı ve güvenilir iki faktörlü yapı önerdiğini bildirmişlerdir. Ayrıca ölçekten alınan puanların depresif semptomlarla güçlü bir biçimde ilişkili bulunduğu ortaya koyulmuştur. İkinci çalışmada, ölçekteki düşük puanlar ile birey için anlamlı stresli bir olaya ilişkin olumsuz stres değerlendirmeleri (daha fazla algılanan tehdit ve kontrol edilemezlik) arasında ilişki bulunmuştur. Üçüncü çalışmada, ölçeğin duygu bileşeni üzerindeki bilişsel kontrolden alınan düşük puanlar, akut psikososyal stres etkeninden sonra artan negatif etki ve kötüleşmiş kortizol yanıtını öngörmüştür. Ayrıca ölçeğin yapı geçerliği için gerçekleştirilen faktör analizi, ölçeğin iki faktörlü yapıya sahip olduğunu göstermiştir. Ölçüm aracının faktör analizi, Temel Bileşenler Analizi (PCA) Promax döndürme yöntemi kullanılarak gerçekleştirilmiştir. Ölçeğin iki faktörlü yapısının alternatif tek ve üç faktörlü modellere göre daha iyi uyum değerleri gösterdiği rapor edilmiştir (Gabrys ve ark., 2018).

Bilişsel Kontrol ve Esneklik Ölçeği, birbirinden farklı ancak birbiriyle örtüşen iki faktörden oluşmaktadır. Ölçeğin duygular üzerinde bilişsel kontrol faktörü bireyin, stresli bir durumda aniden ortaya çıkan ve tekrarlayıcı olumsuz düşünce ve duygularını kontrol edebilme düzeyini değerlendirmektedir. Duyguları üzerinde daha fazla bilişsel kontrol sahibi olduğunu algılayan bireyler, dikkatlerini olumsuz bilişsel ve duygusal durumlardan daha kolay uzaklaştırarak çabalarını doğrudan stresli bir durumu çözmeye odaklayabilmektedirler. Buna karşılık, duyguları üzerinde düşük bilişsel kontrol algılayan bireylerin tekrarlayan olumsuz düşüncelere ve olumsuz duygulara sahip olması daha muhtemeldir (Gabrys ve ark., 2018). Gabrys ve arkadaşları (2018) duygular üzerindeki düşük bilişsel kontrolün yüksek düzeyde tekrarlayan düşünce ve ruminasyonla, stresli bir durumun ardından artan olumsuz duygularla ve sonuç olarak yüksek depresyon belirtileri 
ile ilişkili olduğunu bulmuşlardır. Ölçeğin değerlendirme ve başa çıkma esnekliği faktörü ise, bireyin stresli bir durumun detaylı ve uygun değerlendirmesini ve ayrıca çeşitli başa çıkma stratejilerinin seçimini kolaylaştırabilen bir dizi çaba içeren davranışlarda bulunma becerisini değerlendirmektedir. Değerlendirme ve başa çıkma esnekliği faktöründeki yüksek puanlar, tepki vermeden önce stresli durumlara birden fazla bakış açısıyla yaklaşma, stresli durumları yeniden değerlendirerek olumsuz düşünce ve duyguları yönetme ve uygun olanı seçmeden önce birden fazla alternatif başa çıkma stratejisi oluşturma eğilimini gösterir. Düşük düzeyde değerlendirme ve başa çıkma esnekliği ise daha kolay ya da otomatik olarak yanıt verme eğilimini yansıtmaktadır. Ayrıca, daha ani bilişsel, duygusal ve davranışsal tepkilerle sonuçlanmaktadır (Gabrys ve ark., 2018).

Yurt içindeki ilgili araştırmalar incelendiğinde, bilişsel esnekliğin ölçümüne ilişkin ölçek uyarlama çalışmaları göze çarpmaktadır. Örneğin, Martin ve Rubin (1995) tarafından geliştirilen Bilişsel Esneklik Ölçeği, Çelikkaleli (2014) tarafından; Dennis ve Vander Wal (2010) tarafından geliştirilen Bilişsel Esneklik Envanteri, Gülüm ve Dağ (2012) tarafından Türkçe'ye uyarlanmıştır. Bunun yanında ergenlerin bilişsel esneklik düzeylerini belirleyebilmek amacıyla Bilgin (2009) tarafından Bilişsel Esneklik Ölçeği geliştirilmiştir. $\mathrm{Bu}$ araştırmada ise stresli durumlarda bireylerin bilişsel kontrol ve esneklik düzeylerini ölçme özelliği ile diğer ölçüm araçlarından farklılaşan Bilişsel Kontrol ve Esneklik Ölçeği'nin (Gabrys ve ark., 2018) yurt içi alan yazına kazandırılması amaçlanmıştır. Ölçeğin geçerlik ve güvenirliğine ilişkin daha fazla destek sağlamak amaciyla araştırma üç aşamada yürütülmüştür.

\section{YÖNTEM}

\section{Katılımcılar}

Çalışmanın veri toplama süreci üç aşamadan oluşmaktadır. Birinci aşamaya Akdeniz Bölgesi'ndeki bir devlet üniversitesinin Eğitim Fakültesi'ne bağlı İngilizce Öğretmenliği Programı'nda öğrenim gören 31 kadın (\%66) ve 16 erkek (\%34), toplam 47 öğrenci katılmıştır. Katılımcıların yaş ranjı 18 - 22 olup yaş ortalaması 19.97'dir $(S S=0.82)$. İkinci aşamaya ise, 2019 yılı bahar döneminde Akdeniz, Karadeniz ve İç Anadolu Bölgeleri'nde yer alan farklı üniversitelerin, Eğitim Fakülteleri'nde lisans ve yüksek lisans eğitimi alan 157 kadın (\%65), 84 (\%35) erkek, toplam 241 öğrenci katılım göstermiştir. $\mathrm{Bu}$ aşamada araştırmaya katılanların yaş ranjı 18-34 arasında olup, yaş ortalaması 22.72'dir $(S S=4.54)$. Üçüncü ve son aşamaya 2018-2019 güz döneminde Akdeniz Böl- 
gesi’ndeki bir devlet üniversitesinin Eğitim Fakültesi ve Diş Hekimliği Fakültesi’nde öğrenim gören 157 kadın (\%45) ve 195 erkek (\%55) olmak üzere toplam 352 öğrenci katılmıştır. Katılımcıların 96'sı (\%27) Rehberlik ve Psikolojik Danışmanlık Programı, 29’u (\%8) Diş Hekimliği Programı öğrencileri olup, geriye kalan 227 öğrenci (\%65) Eğitim Fakültesi'nde pedagojik formasyon eğitimi alan öğrencilerden oluşmaktadır. Katılımcıların yaş ranjı 18-38 olup yaş ortalaması 22.69 ' dur $(S S=4.24)$.

\section{Veri Toplama Araçları}

Bilişsel Kontrol ve Esneklik Ölçeği (BKEÖ). Gabrys ve arkadaşları (2018) tarafından geliştirilen ölçek bireyin araya giren, istenmeyen (olumsuz) düşünce ve duyguları üzerindeki kontrol sağlama ve stresli bir durumla esnek bir şekilde başa çıkma becerisini ölçmektedir. Değerlendirme ve başa çıkma esnekliği ve duygular üzerinde bilişsel kontrol olmak üzere iki faktöre sahip olan ölçüm aracı, her iki faktörde 9 madde olmak üzere toplam 18 maddeden oluşmaktadır. Araştırmacılar ölçeğin Cronbach Alpha güvenirlik katsayılarını değerlendirme ve başa çıkma esnekliği faktörü için .89 ve .93 olarak, duygular üzerinde bilişsel kontrol faktörü için .90 olarak rapor etmişlerdir. Öz bildirime dayalı ölçüm aracında, katılımcılardan stresli durumlar olumsuz düşüncelerini ve duygularını tetiklediğinde genel olarak ne düşündüklerini, ne hissettiklerini ve ne yaptıklarını 7'li Likert derecelendirme ölçeği ( 1 = Hiç katılmıyorum, 7 = Tamamen katılıyorum) arasında bildirmeleri istenmektedir. Ölçekte yer alan bazı örnek maddeler "Nasıl bir adım atacă̆ıma karar vermeden önce elimdeki seçenekleri tartarım" ve "Hoş olmayan düşüncelerden ve duygulardan kurtulmak benim için kolaydır" şeklindedir.

Araştırmaya başlamadan önce ölçüm aracını geliştiren araştırmacılardan birinci yazar ile e-posta aracılığıyla iletişime geçilmiş ve araştırma hakkında bilgi verilerek ölçeğin uyarlanması hususunda onayı alınmıştır. Ölçüm aracı İngiliz Dili Eğitimi’nde lisans derecesine sahip araştırmacı tarafından Türkçe'ye çevrilmiştir. Maddelerin Türkçe çevirisinden sonra Mütercim Tercümanlık Bölümü’nde lisans, Eğitimde Program Geliştirme Bölümü'nde doktora derecesine sahip bir uzman tarafından ölçek maddelerinin geri çevirisi yapılmış, çevirilerin tutarlı olup olmadığı incelenmiştir. Daha sonra birisi İngiliz Dili Eğitimi Anabilim Dalı'ndan, ikisi Rehberlik ve Psikolojik Danışmanlık Anabilim Dalı'ndan üç öğretim üyesinin görüşleri alınarak ölçeğin Türkçe formuna son hali verilmiştir. Uygulamaya geçmeden önce Eğitim Fakültesi öğrencilerinden 10 kişilik küçük bir gruba ön uygulama yapılmış ve maddelerin anlaşılabilirliği kontrol edilmiştir. Uyarlanan ölçüm aracı Ek 1'de sunulmuştur. 
Bilişsel Esneklik Envanteri (BEE). Orijinal adı Cognitive Flexibility Inventory olan ölçüm arac1, bireylerin uyumsuz düşüncelerini sorgulamaları ve uyumsuz düşüncelerini uyumlu düşünceler ile başarılı bir şekilde değiştirmeleri için gerekli olan bilişsel esnekliği ölçmek amacıyla geliştirilmiştir (Dennis ve Vander Wal, 2010). Alternatifler ve kontrol olmak üzere iki faktöre sahip olan ölçüm aracı her iki faktörde 10 madde olmak üzere toplam 20 maddeden oluşmaktadır. Ölçeğin Türkçe'ye uyarlama çalışması Gülüm ve Dağ (2012) tarafından yapılmıştır. Açımlayıcı faktör analizi bulgularına dayalı olarak ölçüm aracının iki faktörlü yapısının Türk örneklem üzerinde geçerli olduğu rapor edilmiştir. Cronbach Alpha güvenirlik katsayıları, alternatifler için .90, kontrol için .89, ölçeğin tümü için .85 olarak hesaplanmıştır. Bu araştırmada, Cronbach Alpha katsayıları sırasıyla $.91, .83$ ve .90 olarak hesaplanmıştır.

Sürekli Umut Ölçeği (SUÖ). Orijinal adı Dispositional Hope Scale olan ölçüm aracı, bireylerin sürekli umut düzeylerini belirleyebilmek amacıyla geliştirilmiştir (Snyder ve ark., 1991). Alternatif yollar düşüncesi (pathways) ve amaca güdülenme (agency) olarak iki faktöre sahip ölçek, toplam 12 maddeden oluşmaktadır. Faktörlerde dörder madde yer almaktadır ve kalan dört madde umutla ilişkili olmayan dolgu maddelerdir. Ölçeğin Türkçe'ye uyarlanması Tarhan ve Bacanlı (2015) tarafından üniversite öğrencileri üzerinde gerçekleştirilmiştir. Doğrulayıcı faktör analizi sonuçlarına göre iki faktörlü modelin Türk örnekleminde iyi uyum değerlerine sahip olduğu rapor edilmiştir (GFI = $.96, \mathrm{AGFI}=.92, \mathrm{RMR}=.08, \mathrm{NNFI}=.94, \mathrm{RFI}=.90, \mathrm{CFI}=.96, \mathrm{RMSEA}=.077)$. Ölçeğin Cronbach Alpha güvenirlik katsayısı .84 olarak bulunurken test tekrar test güvenirlik katsayısı ise .86 olarak hesaplanmıştır. Bu araştırmada Cronbach Alpha güvenirlik katsayıları alternatif yollar faktörü için .76, amaca güdülenme faktörü için .74, ölçeğin tümü için .84 olarak hesaplanmıştır.

Algılanan Stres Ölçeği (ASÖ). Ölçek bireylerin algılanan stres seviyelerini belirlemek için Cohen ve arkadaşları (1983) tarafından geliştirilmiştir. 10 maddeden oluşmakta olan ölçüm aracından alınan yüksek puan, birey tarafından algılanan stres seviyesinin yüksek olduğunu göstermektedir. Ölçüm aracının Türkçe'ye uyarlama çalışmasında yapı geçerliğini test etmek amacıyla Beck Depresyon Envanteri (Beck, Ward, Mendelson, Mock ve Erbaugh, 1961) ve Spielberger'in Durumluk-Sürekli Kaygı Envanteri (Spielberger, Gorsuch ve Luschene, 1970) ile ilişkileri incelenmiş ve diğer yapılarla aralarında anlamlı ilişkiler bulunmuştur (Yerlikaya ve İnanç, 2007). Ölçeğin Cronbach Alpha güvenirlik katsayısı .84 olarak rapor edil- 
miştir. Ölçeğin bu araştırma için hesaplanan Cronbach Alpha güvenirlik katsayısı da .84'dür.

\section{İşlem}

Araştırmanın birinci aşamasında, ölçüm aracının dilsel eş değerliğini sınamak amaçlanmıştır. Bu amaçla her iki dile hakim olan katılımcılara, ölçeğin orijinal formu ile Türkçe formu iki hafta ara ile uygulanarak iki form arasındaki ilişkiler incelenmiştir. Bu amaçla 47 öğrenciye, ölçeğin önce İngilizce formu uygulanmış, iki hafta sonra da ölçeğin Türkçe formu uygulanmıştır. Veriler sınıf ortamında toplanmış olup gönüllülü̈k esas alınmıştır.

İkinci aşamada, ölçüm aracının yapı geçerliğini ve güvenirliğini sınamak amaçlanmıştır. Bu amaçla ölçüm aracının iki faktörlü yapısının Türk üniversite öğrencileri üzerinde bir model olarak doğrulanıp doğrulanmadığı sınanmış, ayrıca madde-toplam puan korelasyonu ve Cronbach Alpha güvenirlik katsayıları hesaplanmıştır. İkinci aşamada veri toplama aracı için internet üzerinden çevrimiçi ortamda form oluşturulmuştur. Araştırmada uygun örnekleme yöntemi kullanılmıştır. Cohen, Manion ve Morrison (2007), uygun örneklemeyi katılımcı olarak en yakın bireylerin seçilmesi ve gerekli örneklem büyüklüğü elde edilene veya erişilebilir olana kadar bu sürece devam edilmesi olarak açıklamaktadır. Bu yönteme dayalı olarak sosyal medya ağları aracılığıyla ulaşılabilen katılımcılar araştırmaya davet edilmiş ve yeterli sayıya ulaşana kadar çevrimiçi ortamda veri toplamaya devam edilmiştir. Verilerin toplanması yaklaşık bir hafta sürmüştür.

Son aşamada ölçüm aracının diğer yapılarla ilişkilerinin incelenmesi kapsamında ASÖ (Cohen ve ark., 1983) ve SUÖ (Snyder ve ark., 1991) kullanılmıştır. Düşük bilişsel esneklik seviyesine sahip kişiler duygusal stresin azaltılmasında bilişsel yeniden yapılandırmayı, bilişsel olarak esnek bireyler gibi kullanamazlar. Gabrys ve arkadaşları (2018) ölçeğin geliştirilmesinde BKEÖ’den alınan puanlar ile depresif semptomlar ve negatif stres değerlendirmeleri (örn., daha fazla algılanan tehdit ve kontrol edilemezlik) arasında yüksek düzeyde ilişki olduğunu ortaya koymuşlardır. Bu nedenle iki ölçüm aracı arasında negatif yönde korelasyon beklenmektedir. Diğer taraftan orijinal ölçeğin geliştirme çalışmasından farklı olarak ölçüm aracının pozitif bir değişken olarak SUÖ ile arasındaki ilişkilerin ortaya konması amaçlanmıştır. Umut, bireylerin yaşamdaki hedeflerini ortaya koymasını, bu hedeflere ulaşmak için alternatif yollar geliştirmesini ve bu alternatifleri kullanmaya yönelik motivasyonunu devam ettirebilmesi ile ilişkili alg1larını kapsamaktadır (Snyder, Lopez, Shorey, Rand ve Feldman, 2003). İki yapıya iliş- 
kin kavramsal açıklamalara dayalı olarak bilişsel esneklik ve umut arasında pozitif yönde ilişki beklenmektedir. Ölçüm araçları bilgilendirilmiş onam eşliğinde, katılımcılara sınıf ortamında araştırmacı tarafından uygulanmıştır. Uygulamalar 2018-2019 Eğitim Öğretim Güz Dönemi’nde gerçekleştirilmiştir.

\section{Veri Analizi}

İlk aşamada, ölçek formları arasındaki korelasyon değerlerine yönelik yapılacak analizi belirlemek amacıyla veriler normallik varsayımları açısından incelenmiştir. Verilerin normal dağılıma uygunluğunu belirlemek için merkezi eğilim ölçüleri ile basıklık ve çarpıklık değerleri dikkate alınmıştır. Merkezi eğilim ölçüleri bakımından ortalama, ortanca ve tepe değerin birbirine yakın değerler alması ve çarpıklık ve basıklık değerlerinin \pm 1.5 değerleri arasında olmasından dolayı (Bkz. Tablo 1) verilerin normal dağılımdan önemli bir sapma göstermediği sonucuna varılmıştır (Can, 2015; Tabachnick ve Fidell, 2013). Ölçeğin orijinal formu ile Türkçe formu arasındaki ilişkiler Pearson momentler çarpımı korelasyon analizi ile incelenmiştir (Bkz. Tablo 1). Analizler, orijinal ölçekteki faktörler kullanılarak gerçekleştirilmiştir. Verilerin analizinde SPSS 24.0 paket programından yararlanılmıştır.

İkinci aşamada BKEÖ’nün yapı geçerliğini test etmek amacıyla doğrulayıcı faktör analizi (DFA) yapılmıştır. Analiz gerçekleştirilmeden önce verilerin DFA için uygunluğu test edilmiştir. Uç değerlerin belirlenmesi amacıyla Mahalanobis uzaklık değerleri oluşturulmuş, analizleri olumsuz etkileyecek uç değere rastlanmamıştır. Ayrıca test maddelerinin birbirleriyle ilişkileri incelenmiş, .80 üzerinde bir değer olmadığı için (en yüksek .64) çoklu doğrusal bağlantı problemine rastlanmamıştır (Büyüköztürk, 2011). Ölçeğin madde geçerliğini sınamak amacıyla madde-toplam puan ve madde-faktör toplam puan korelasyon katsayıları kullanılmıştır. Güvenirliğini sınamak içinse Cronbach Alpha güvenirlik katsayıları hesaplanmıştır. Analizlerin gerçekleştirilmesinde, SPSS 24.0 ve LISREL 8.8 paket programları kullanılmıştır.

Üçüncü aşamada, ölçeğin geçerliğine ilişkin analizler gerçekleştirilmeden önce veriler kayıp değerler, uç değerler, çoklu doğrusal bağlantılılık ve çok değişkenli normallik varsayımları kapsamında incelenmiştir. Veri setinde kayıp değere rastlanmamıştır. Uç değerlerin belirlenmesi için Mahalanobis uzaklık değerleri hesaplanmış, analizleri olumsuz etkileyecek uç değer olmadığı sonucuna varılmıştır. BKEÖ’den (Gabrys ve ark., 2018) elde edilen veriler üzerinde ölçek maddelerinin birbirleriyle korelasyon değerleri ince- 
lenmiş, çoklu bağlantı problemine yol açabilecek bir değer olmadiğı görülmüştür (en yüksek .68). Ölçekler ve faktörler arasındaki ilişkileri ortaya koyabilmek amacıyla ölçek toplam puanları ve faktör toplam puanları ile elde edilen puanların ortalamaları çarpıklık ve basıklık değerleri hesaplanmıştır. Çarpıklık ve basıklık değerlerinin \pm 1.5 değerleri arasında olması normal dağılım için destek olarak değerlendirilmiş (Tabachnick ve Fidel, 2013) ve parametrik testlerden Pearson momentler çarpımı korelasyon analizinin kullanılabileceğine karar verilmiştir. Ölçüm aracının madde geçerliği kapsamında, madde-toplam korelasyonu değerleri ile ölçekten alınan toplam puana göre belirlenen alt \%27 ve üst \%27'lik grupların ölçek maddelerine verdikleri yanıtlar arasındaki farklılıklar karş1laştırılmıştır. Bu karşılaştırmalar bağımsız örneklemler için $t$-testi aracılığıyla incelenmiştir. Ölçeğin güvenirliği için Cronbach Alpha güvenirlik katsayısı kullanılmıştır. Analizlerin gerçekleştirilmesinde SPSS 24.0 paket programı kullanılmıştır.

\section{BULGULAR}

\section{Birinci Aşamaya İlişkin Bulgular}

$\mathrm{Bu}$ aşamada, ölçeğin dil geçerliğini sınamak amacıyla aynı çalışma grubuna iki hafta arayla ölçüm aracı uygulanmıştır. Ölçeklerden alınan puanlara ilişkin betimsel istatistikler ve Pearson momentler çarpımı korelasyon katsayısı değerleri Tablo 1'de sunulmuştur.

Tablo 1. Dilsel Eşdeğerliğe İlişskin Betimsel İstatistikler ve Pearson Korelasyon Katsayıları.

\begin{tabular}{llcccccc}
\hline Değişkenler & & $\overline{\boldsymbol{x}}$ & $\boldsymbol{O r t .}$ & Tepe d. & Çar. & Bas. & $\boldsymbol{r}$. \\
\hline Değerlendirme ve Başa Çıkma & İngilizce Form & 47.85 & 49.00 & 49.00 & .09 & .49 & $.88^{*}$ \\
Esnekliği Faktörü & Türkçe Form & 47.23 & 49.00 & 50.00 & -.29 & -.46 & \\
Duygular Üzerinde Bilişsel & İngilizce Form & 33.87 & 33.00 & 33.00 & .31 & .23 & $.96^{*}$ \\
Kontrol Faktörü & Türkçe Form & 33.57 & 32.00 & 31.00 & .40 & -.10 & \\
Bilişsel Kontrol ve Esneklik & İngilizce Form & 77.72 & 78.00 & 80.00 & .32 & -.22 & $.95^{*}$ \\
Ölçeği Toplam & Türkçe Form & 80.80 & 80.00 & 80.00 & .08 & .33 & \\
\hline
\end{tabular}

$N=47,{ }^{*} p<.01$

Tablo 1'de görüldüğü üzere, iki ölçüm arasındaki Pearson korelasyon katsayıları değerlendirme ve başa çıkma esnekliği faktörü için .88 $(p<.01)$, duygular üzerinde bilişsel kontrol faktörü için $.96(p<.01)$ ve ölçeğin tümü için $.95(p<.01)$ olarak hesaplanmıştır.

\section{İkinci Aşamaya İliş̧kin Bulgular}

İlk analizde model uyum değerleri $\chi^{2} / s d=2.96, \mathrm{NFI}=.93, \mathrm{CFI}=.95$ ve $\mathrm{RMSEA}=$ .09 olarak hesaplanmıştır. Buna rağmen, analiz sonuçlarının model uyum değerlerini artırabilecek modifikasyon önerileri sunduğu gözlenmiştir. İkinci analizde modifikas- 
yon önerileri doğrultusunda 12. ve 13. maddeler arasında modifikasyon yapılmış ve RMSEA değerinin .08'e düştüğü, dolayısıyla modelin iyileştiği ortaya çıkmıştır.

Modifikasyon sonrası uyum değerleri incelendiğinde $\chi^{2} / s d=2.63, \mathrm{NFI}=.94, \mathrm{CFI}=$ $.96, \mathrm{GFI}=.86, \mathrm{AGFI}=.82, \mathrm{IFI}=.96, \mathrm{SRMR}=.07$ ve $\mathrm{RMSEA}=.08$ olduğu görülmüştür. Ölçek maddelerinin faktör yüklerine ve $t$ değerlerine ilişkin DFA bulguları Şekil 1 'de sunulmuştur.

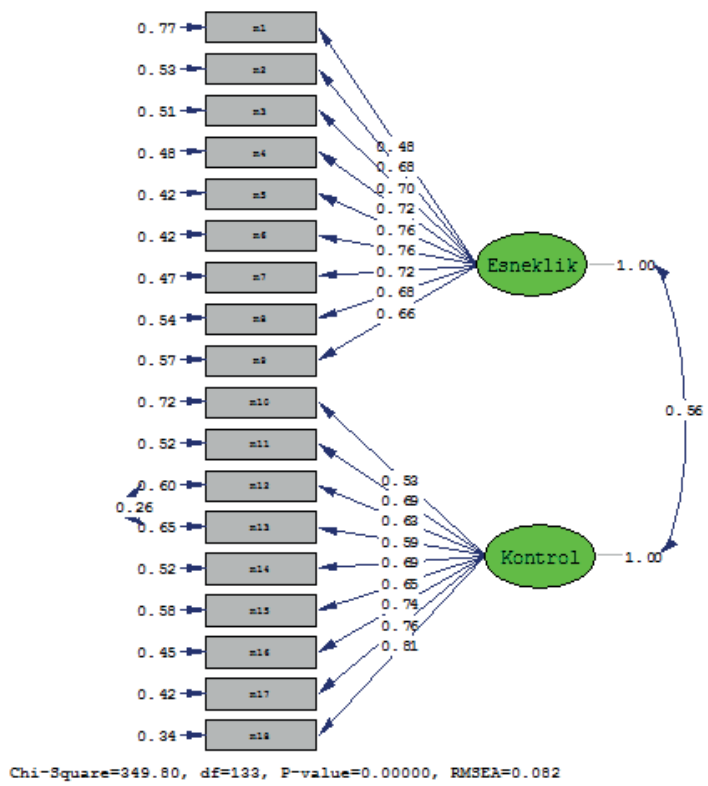

Şekil 1. Bilişsel Kontrol ve Esneklik Ölçeği’ne İlişkin Path Diagramı ve Faktör Yükleri

Şekil 1'deki değerler incelendiğinde, tüm $t$ değerlerinin 7.54 ile 14.58 arasında değiştiği ve $p<.001$ düzeyinde anlamlı olduğu görülmüştür. Ölçek maddelerinin faktör yük değerleri .48 ve .81 arasında değişmektedir.

Madde-toplam puan korelasyonu bulguları, ölçüm aracındaki maddeler ile ölçüm aracından alınan toplam puan arasındaki ilişkilerin .50 ile .73 arasında değiştiğini ortaya koymuştur. Ayrıca madde-faktör toplam puanı korelasyonları hesaplanmış ve ölçüm aracındaki maddeler ile faktör toplam puanları arasındaki ilişkilerin duygular üzerinde bilişsel kontrol faktörü için .31 ile .71 arasında, değerlendirme ve başa çıkma esnekliği faktörü için .30 ile .83 arasında değiştiği görülmüştür. 
Ölçeğin güvenirliği için hesaplanan Cronbach Alpha katsayıları duygular üzerinde bilişsel kontrol faktörü için .88, değerlendirme ve başa çıkma esnekliği faktörü için .88, ölçeğin tümü için .90 düzeyinde olduğu belirlenmiştir.

\section{Üçüncü Aşamaya İlişkin Bulgular}

Bilişsel Kontrol ve Esneklik Ölçeği'nin yaklaşan (convergent) geçerliğini test etmek için BEE (Dennis ve Vander Wal, 2010), diğer yapılarla ilişkilerini incelemek amacıyla ASÖ (Cohen ve ark., 1983) ve SUÖ (Snyder ve ark., 1991) kullanılmıştır. Ölçekler arası korelasyon katsayıları Tablo 2'de sunulmuştur.

Tablo 2. Ölçekler Arası Korelasyon Katsayıları

\begin{tabular}{|c|c|c|c|c|c|c|c|c|c|c|c|c|c|c|}
\hline Değişkenler & Ort. & $S S$ & Çarpıklık & Basılklık & 1 & 2 & 3 & 4 & 5 & 6 & 7 & 8 & 9 & 10 \\
\hline $\begin{array}{l}\text { 1. Bilişsel Kontrol ve Esneklik } \\
\text { Ölçeği- Değerlendirme ve Başa } \\
\text { Çıma Esnekliği }\end{array}$ & 47.12 & 9.51 & -.79 & 1.08 & (.91) & & & & & & & & & \\
\hline $\begin{array}{l}\text { 2. Bilişsel Kontrol ve Esneklik } \\
\text { Ölçeği- Duygular Üzerinde } \\
\text { Bilişsel Kontrol }\end{array}$ & 36.49 & 10.66 & .18 & -.21 & $.53^{*}$ & $(.85)$ & & & & & & & & \\
\hline $\begin{array}{l}\text { 3. Bilişsel Kontrol ve Esneklik } \\
\text { Ölçeği }\end{array}$ & 83.61 & 17.63 & -.18 & .38 & $.86^{*}$ & $.89^{*}$ & $(.91)$ & & & & & & & \\
\hline $\begin{array}{l}\text { 4. Bilişsel Esneklik Envanteri- } \\
\text { Alternatifler }\end{array}$ & 62.67 & 9.45 & -.46 & .26 & $.66^{*}$ & $.41^{*}$ & $.61^{*}$ & $(.91)$ & & & & & & \\
\hline $\begin{array}{l}\text { 5. Bilişsel Esneklik Envanteri- } \\
\text { Kontrol }\end{array}$ & 28.46 & 6.93 & .09 & -.63 & $.45^{*}$ & $.63^{*}$ & $.62 *$ & $.51^{*}$ & $(.83)$ & & & & & \\
\hline 6.Bilişsel Esneklik Envanteri & 91.14 & 14.29 & .06 & -.37 & $.66^{*}$ & $.58^{*}$ & $.70^{*}$ & $.91^{*}$ & $.82 *$ & $(.90)$ & & & & \\
\hline $\begin{array}{l}\text { 7. Sürekli Umut Ölçeği } \\
\text { - Alternatif Yollar }\end{array}$ & 25.66 & 4.50 & -.67 & .52 & $.63^{*}$ & $.39^{*}$ & $.58^{*}$ & $.67^{*}$ & $.49 *$ & $.68^{*}$ & $(.76)$ & & & \\
\hline $\begin{array}{l}\text { 8. Sürekli Umut Ölçeği } \\
\text { - Amaca Güdülenme }\end{array}$ & 24.30 & 4.73 & -.42 & .00 & $.50^{*}$ & $.37^{*}$ & $.49^{*}$ & $.56^{*}$ & $.48^{*}$ & $.60 *$ & $.68^{*}$ & $(.74)$ & & \\
\hline 9. Sürekli Umut Ölçeği & 49.97 & 8.46 & -.52 & .14 & $.62 *$ & $.41^{*}$ & $.58^{*}$ & $.67 *$ & $.53 *$ & $.70^{*}$ & $.91^{*}$ & $.92 *$ & $(.84)$ & \\
\hline 10. Algılanan Stres Ölçeği & 30.32 & 6.84 & -.15 & .20 & $-.37 *$ & $-.53^{*}$ & $-.53^{*}$ & $-.36^{*}$ & $-.59^{*}$ & $-.52 *$ & $-.32 *$ &.$-39 *$ & $-.40^{*}$ & (.84) \\
\hline
\end{tabular}

Tablo 2'deki korelasyon değerleri incelendiğinde, duygular üzerinde bilişsel kontrol faktörü, değerlendirme ve başa çıkma esnekliği faktörü ve ölçeğin tümünün, BEE (Dennis ve Vander Wall, 2010) ve faktörleri ile (alternatifler ve kontrol) pozitif yönde orta ve yüksek düzeylerde anlamlı ilişkilere sahip olduğu görülmektedir. Bunun yanında, SUÖ (Snyder ve ark., 1991) ve faktörleri (alternatifler ve amaca yönelik güdülenme) ile pozitif yönde orta düzeyde ilişkilere sahiptir. Ayrıca ASÖ (Cohen ve ark., 1983) ile negatif yönde orta düzeyde anlamlı ilişkiler bulunmuştur. Ölçeğin iç tutarlılığına destek olarak, BKEÖ’den alınan toplam puan ile değerlendirme ve başa çıkma esnekliği $(r(350)=.86$, $p<.01)$ ve duygular üzerinde bilişsel kontrol $(r(350)=.89, p<.01)$ faktörleri arasında 
yüksek düzeyde anlamlı ilişkilere ve iki faktörün birbirleri ile orta düzeyde ilişkiye $(r(350)=.53, p<.01)$ sahip olduğu görülmüştür (Bkz. Tablo 2).

Madde-toplam puan korelasyonu bulguları ölçüm aracındaki maddelerin .46 ve .69 arasında değer aldığını göstermiştir. Ölçekten alınan toplam puana göre belirlenen alt \%27 ve üst \%27'lik grupların ölçek maddelerine verdikleri yanıtlar arasındaki farklılıklara ilişkin gerçekleştirilen bağımsız örneklemler için $t$-testi sonuçları Tablo 3'de sunulmuştur.

Tablo 3. Maddelerin Alt-Üst Grup Ortalamalarına Yönelik $t$-Testi Bulguları

\begin{tabular}{|c|c|c|c|c|c|c|c|}
\hline Madde No & Grup & $N$ & Ort & $S S$ & $s d$ & $t$ & $p$ \\
\hline Madde 1 & $\begin{array}{l}\text { Alt Grup } \\
\text { Üst Grup }\end{array}$ & $\begin{array}{l}95 \\
95\end{array}$ & $\begin{array}{l}4.46 \\
6.44\end{array}$ & $\begin{array}{l}1.58 \\
0.69\end{array}$ & 188 & -11.115 & $<.001$ \\
\hline Madde 2 & $\begin{array}{l}\text { Alt Grup } \\
\text { Üst Grup }\end{array}$ & $\begin{array}{l}95 \\
95\end{array}$ & $\begin{array}{l}3.16 \\
5.41\end{array}$ & $\begin{array}{l}1.38 \\
1.55\end{array}$ & 188 & -10.486 & $<.001$ \\
\hline Madde 3 & $\begin{array}{l}\text { Alt Grup } \\
\text { Üst Grup }\end{array}$ & $\begin{array}{l}95 \\
95\end{array}$ & $\begin{array}{l}4.52 \\
6.24\end{array}$ & $\begin{array}{l}1.49 \\
0.79\end{array}$ & 188 & -9.884 & $<.001$ \\
\hline Madde 4 & $\begin{array}{l}\text { Alt Grup } \\
\text { Üst Grup }\end{array}$ & $\begin{array}{l}95 \\
95\end{array}$ & $\begin{array}{l}2.68 \\
5.40\end{array}$ & $\begin{array}{l}1.49 \\
1.48\end{array}$ & 188 & -12.563 & $<.001$ \\
\hline Madde 5 & $\begin{array}{l}\text { Alt Grup } \\
\text { Üst Grup }\end{array}$ & $\begin{array}{l}95 \\
95\end{array}$ & $\begin{array}{l}3.51 \\
5.98\end{array}$ & $\begin{array}{l}1.44 \\
0.93\end{array}$ & 188 & -14.002 & $<.001$ \\
\hline Madde 6 & $\begin{array}{l}\text { Alt Grup } \\
\text { Üst Grup }\end{array}$ & $\begin{array}{l}95 \\
95\end{array}$ & $\begin{array}{l}4.14 \\
6.30\end{array}$ & $\begin{array}{l}1.39 \\
0.71\end{array}$ & 188 & -13.444 & $<.001$ \\
\hline Madde 7 & $\begin{array}{l}\text { Alt Grup } \\
\text { Üst Grup }\end{array}$ & $\begin{array}{l}95 \\
95\end{array}$ & $\begin{array}{l}2.65 \\
5.70\end{array}$ & $\begin{array}{l}1.56 \\
1.15\end{array}$ & 188 & -15.261 & $<.001$ \\
\hline Madde 8 & $\begin{array}{l}\text { Alt Grup } \\
\text { Üst Grup }\end{array}$ & $\begin{array}{l}95 \\
95\end{array}$ & $\begin{array}{l}2.46 \\
5.11\end{array}$ & $\begin{array}{l}1.43 \\
1.71\end{array}$ & 188 & -11.571 & $<.001$ \\
\hline Madde 9 & $\begin{array}{l}\text { Alt Grup } \\
\text { Üst Grup }\end{array}$ & $\begin{array}{l}95 \\
95\end{array}$ & $\begin{array}{l}3.56 \\
6.06\end{array}$ & $\begin{array}{l}1.45 \\
0.97\end{array}$ & 188 & -13.869 & $<.001$ \\
\hline Madde 10 & $\begin{array}{l}\text { Alt Grup } \\
\text { Üst Grup }\end{array}$ & $\begin{array}{l}95 \\
95\end{array}$ & $\begin{array}{l}3.93 \\
6.18\end{array}$ & $\begin{array}{l}1.39 \\
0.81\end{array}$ & 188 & -13.622 & $<.001$ \\
\hline Madde 11 & $\begin{array}{l}\text { Alt Grup } \\
\text { Üst Grup }\end{array}$ & $\begin{array}{l}95 \\
95\end{array}$ & $\begin{array}{l}2.41 \\
4.68\end{array}$ & $\begin{array}{l}1.60 \\
1.65\end{array}$ & 188 & -9.613 & $<.001$ \\
\hline Madde 12 & $\begin{array}{l}\text { Alt Grup } \\
\text { Üst Grup }\end{array}$ & $\begin{array}{l}95 \\
95\end{array}$ & $\begin{array}{l}4.38 \\
6.27\end{array}$ & $\begin{array}{l}1.44 \\
0.73\end{array}$ & 188 & -11.319 & $<.001$ \\
\hline Madde 13 & $\begin{array}{l}\text { Alt Grup } \\
\text { Üst Grup }\end{array}$ & $\begin{array}{l}95 \\
95\end{array}$ & $\begin{array}{l}4.09 \\
6.14\end{array}$ & $\begin{array}{l}1.30 \\
0.96\end{array}$ & 188 & -12.315 & $<.001$ \\
\hline Madde 14 & $\begin{array}{l}\text { Alt Grup } \\
\text { Üst Grup }\end{array}$ & $\begin{array}{l}95 \\
95\end{array}$ & $\begin{array}{l}3.78 \\
6.15\end{array}$ & $\begin{array}{l}1.36 \\
0.91\end{array}$ & 188 & -14.032 & $<.001$ \\
\hline Madde 15 & $\begin{array}{l}\text { Alt Grup } \\
\text { Üst Grup }\end{array}$ & $\begin{array}{l}95 \\
95\end{array}$ & $\begin{array}{l}3.44 \\
5.83\end{array}$ & $\begin{array}{l}1.50 \\
1.39\end{array}$ & 188 & -11.336 & $<.001$ \\
\hline Madde 16 & $\begin{array}{l}\text { Alt Grup } \\
\text { Üst Grup }\end{array}$ & $\begin{array}{l}95 \\
95\end{array}$ & $\begin{array}{l}2.77 \\
5.46\end{array}$ & $\begin{array}{l}1.43 \\
1.57\end{array}$ & 188 & -12.290 & $<.001$ \\
\hline Madde 17 & $\begin{array}{l}\text { Alt Grup } \\
\text { Üst Grup }\end{array}$ & $\begin{array}{l}95 \\
95\end{array}$ & $\begin{array}{l}3.95 \\
5.93\end{array}$ & $\begin{array}{l}1.27 \\
1.01\end{array}$ & 188 & -11.793 & $<.001$ \\
\hline Madde 18 & $\begin{array}{l}\text { Alt Grup } \\
\text { Üst Grup }\end{array}$ & $\begin{array}{l}95 \\
95\end{array}$ & $\begin{array}{l}2.43 \\
5.57\end{array}$ & $\begin{array}{l}1.16 \\
1.56\end{array}$ & 188 & -15.709 & $<.001$ \\
\hline
\end{tabular}


Tablo 3'deki değerler incelendiğinde, alt \%27 ve üst \%27'lik grupların ölçek maddelerine verdikleri yanıtlar arasında anlamlı bir farklılık olduğu bulunmuştur $(p<.001)$.

Ölçeğin güvenirliği için hesaplanan Cronbach Alpha güvenirlik katsayıları duygular üzerinde bilişsel kontrol faktörü için .85, değerlendirme ve başa çıkma esnekliği faktörü için .91'dir. Ölçeğin tümü için hesaplanan değer ise .91'dir (Bkz. Tablo 2).

\section{TARTIŞMA}

$\mathrm{Bu}$ araştırmada, Gabrys ve arkadaşları (2018) tarafından geliştirilen BKEÖ’nün Türk üniversite öğrencileri üzerinde psikometrik özellikleri incelenerek yurt içi alan yazına kazandırılması amaçlanmıştır. Dilsel eşdeğerlik çalışması kapsamında iki hafta ara ile gerçekleştirilen uygulamalar arasındaki yüksek düzeyde korelasyon değerleri, ölçeğin orijinal formu ile Türkçe formunun birbirine eş değer olduğuna işaret olarak değerlendirilebilir. Model uyumuna yönelik olarak, $\chi^{2} / s d$ değerinin 3 'ün altında olması mükemmel uyuma, RMSEA ve SRMR değerlerinin .08 ve altında olması iyi uyuma, NFI, CFI ve NNFI değerlerinin .90 ve üzerinde olması iyi uyuma ve .95 ve üzerinde olması mükemmel uyuma, IFI değerinin .90 ve üzerinde olması iyi uyuma, GFI değerinin .90 ve üzerinde olması iyi uyuma, AGFI değerinin .85 ve üzerinde olması kabul edilebilir uyuma işaret olarak gösterilmektedir (Hooper, Coughlan ve Mullen, 2008; Hu ve Bentler, 1999; Jöreskog ve Sörbom, 1993; Kline, 2005; Schermelleh-Engel, Moosbrugger ve Müller, 2003; Marsh ve Hau, 1996; Schumacker ve Lomax, 1996; Tabachnick ve Fidell, 2013). Yapı geçerliğini sınamak amacıyla gerçekleştirilen doğrulayıcı faktör analizi uyum istatistikleri incelendiğinde GFI ve AGFI değerleri kabul edilen sınırların altında görülmektedir. GFI ve AGFI değerleri sıklıkla kullanılmasına rağmen bazı araştırmacılar simülasyon çalışmalarındaki düşük performansları nedeniyle bu değerlerin kullanılmasını önermemektedir (Hu ve Bentler, 1998; Marsh, Balla ve McDonald, 1988). Bunun yanında, doğrulayıcı faktör analizinde birden fazla uyum indeksi elde edilmektedir ve modelin doğruluğu tek bir uyum indeksi ile değil tüm indeksler bir aradayken değerlendirilmektedir (Jöreskog ve Sörbom, 1993). Bu bakımdan model uyum değerleri ve ölçek maddelerinin faktör yük değerleri bir arada değerlendirildiğinde BKEÖ’nün iki faktörlü 18 maddelik yapısının doğrulandığ 1 ve modelin yeterli uyum değerlerine sahip olduğu söylenebilir. Madde analizi bulguları, ölçüm aracındaki maddelerin bireyleri, değerlendirme ve başa çıkma esnekliği ile duygular üzerinde bilişsel kontrol bakımından iyi derecede ayırt edici özelliğe sahip olduğunu göstermektedir. Alan yazında bir 
maddenin faktör yük değerinin en düşük .30 veya .40 olması beklenmektedir (Şencan, 2005). Bunun yanında, ölçeğin tümü ile faktörleri arasındaki yüksek düzeyde korelasyon değerleri ölçeğin iç tutarlılığının yüksek olduğunu ortaya koymaktadır. Ölçeğin BEE (Dennis ve Vander Wal, 2010) ile yüksek düzeyde pozitif ilişkilere sahip olması ise geçerliğine ilişkin bir diğer desteği oluşturmaktadır. Ayrıca Cronbach Alpha değerleri ölçeğin yüksek düzeyde güvenirliğe sahip olduğunu göstermektedir.

Orijinal ölçek çalışmasında (Gabrys ve ark., 2018) ortaya çıkan sonuçlarla bu araştırmada ortaya çıkan sonuçlar karşılaştırıldığında her iki çalışmada da ölçeğin yüksek güvenirlik değerlerine sahip olduğu görülmektedir. Benzer olarak her iki çalışma da madde-faktör yüklerinin birbirine yakın değerler aldığı ve ölçeğin iki faktörü arasında pozitif yönde orta düzeyde ilişkilere sahip olduğu görülmüştür. Buna karşın, orijinal ölçek çalışmasında açımlayıcı yapısal eşitlik modeli bulguları, bu çalışmanın ikinci aşamasında yapılan doğrulayıcı faktör analizinden farklı olarak daha yüksek model uyum değerleri göstermektedir. Model uyum değerleri açısından ortaya çıkan bu farklılık iki çalışmada kullanılan farklı analiz yöntemlerinden kaynaklanıyor olabilir. Gabrys ve arkadaşları (2018) ölçeğin geliştirilmesinde açımlayıcı faktör analizi, ortaya çıkan iki faktörlü modelin doğrulanması için ise açımlayıcı yapısal eşitlik modeli kullanmışlardır. $\mathrm{Bu}$ çalışmada ise önceden kurulan bir modelin bazı parametreler açısından doğruluğunun test edildiği (Çokluk, Şekercioğlu ve Büyüköztürk, 2010) doğrulayıcı faktör analizi kullanılmıştır. Bunun yanında iki çalışma bulguları arasında ortaya çıkan farklılıklar kültürel ve dilsel farklılıklar (Hambleton, 2005) açısından da açıklanabilir.

Bu çalışmada, orijinal ölçek çalışmasında olduğu gibi yaklaşan geçerlik kapsamında ölçüm aracı ile BEE (Dennis ve Vander Wal, 2010) arasındaki ilişkiler incelenmiştir. BKEÖ ve faktörleri ile BEE ve faktörleri arasındaki ilişkilere yönelik elde edilen korelasyon değerlerinin bu çalışmada daha yüksek olduğu görülmüştür. Kavramsal açıklamalar 1şığında beklenildiği gibi BKEÖ’nün değerlendirme ve başa çıkma esnekliği faktörü ile BEE’nin alternatifler faktörü arasında yüksek düzeye yakın ilişkiler bulunmuştur. Bununla birlikte, bu iki faktör arasında önemli bir fark vardır. BEE’nin alternatifler faktörü zor durumlar için çoklu açıklamalar oluşturma eğilimini daha doğrudan ölçerken, BKEÖ’nün değerlendirme ve başa çıkma esnekliği faktörü olumsuz düşünce ve duyguları düzenlemeyi amaçlayan yeniden değerlendirmenin kullanımını ve bunu yaparken bireyin algıladığı zorlukları değerlendirme amacı taşır. Ayrıca BKEÖ’nün duygular üzerinde bilişsel kontrol faktörü ile BEE’nin kontrol faktörü arasında yüksek düzeye yakın 
ilişki olduğu varsayımı da karşılanmıştır. İki faktör arasında güçlü ilişkiler olmasına rağmen önemli farklılıklar da vardır. Özellikle BEE'nin kontrol faktörü zor durumlarda algılanan kontrol edilebilirliği değerlendirirken BKEÖ’nün duygular üzerinde bilişsel kontrol faktörü, bireyin olumsuz düşünce ve duyguların kontrolünü ne ölçüde sağlayabildiğini ölçmektedir (Gabrys ve ark., 2018). Bu farklılıklar nedeniyle BKEÖ’nün alan yazında ihtiyaç duyulan bir ölçüm aracı olduğu düşünülebilir.

Bu çalışmada, ölçüm aracının diğer yapılarla ilişkilerinin incelenmesi kapsamında BKEÖ ve ASÖ (Cohen ve ark., 1983) arasındaki ilişkiler incelenmiştir. Beklenildiği gibi iki ölçek arasında negatif yönde ve orta düzeyde anlamlı ilişki bulunmuştur. Araştırma bulgularının orijinal ölçek çalışmasında ortaya konan bulgularla (Gabrys ve ark., 2018) tutarlı olduğu söylenebilir. Yüksek düzeyde bilişsel esneklik, bilişsel yeniden değerlendirme ve yapılandırma kullanılarak içinde bulunulan duygusal stresin önemli ölçüde azalmasıyla ilişkilendirilmiştir (Johnco, Wuthrich ve Rapee, 2014). Ayrıca araştırmacılar, düşük bilişsel kontrol ve esneklik puanları ile problem odaklı başa çıkma arasında pozitif yönde, duygu odaklı başa çıkma ve kaçınmacı başa çıkma puanları arasında negatif yönde anlamlı ilişki bulmuşlardır (Gabrys ve ark., 2018). Ülkemizde üniversite öğrencileri üzerinde yapılan bir araştırmaya göre, bilişsel esneklik düzeyi arttıkça algılanan stres seviyesi azalmaktadır (Altunkol, 2011). Bu bulgu, araştırmanın sonuçlarını destekler niteliktedir. Olumsuz, istenmeyen, aniden gelen duygular üzerinde kontrol becerisine sahip ve stresli veya zor durumlarda farklı alternatifler yaratabilen bireyler, bu beceriye sahip olmayan bireylere göre daha az stres yaşamaktadırlar.

SUÖ’nün (Snyder ve ark., 1991) alternatifler ve amaca yönelik güdülenme faktörleri ile bu çalışmada uyarlanan ölçüm aracının faktörleri arasında beklenildiği gibi anlamlı düzeyde pozitif ilişkiler bulunmuştur. Snyder ve arkadaşları (1991) umudu, karşılıklı iki bileşenden (amaca güdülenme ve alternatif yollar) oluşan bilişsel bir yapı olarak kavramsallaştırmaktadırlar. Umutlu bireyler, olumlu duygular yaşamakta ve başarı önündeki engelleri stres yaratan faktörler olarak değil, aşılması gereken güçlükler olarak görme eğilimi göstermektedirler (Oettingen ve Gollwitzer, 2002). Kavramsal açıklamalar ve bu araştırmada ortaya çıkan korelasyon sonuçları iki değişkenin birbiri ile ilişkili olduğunu ortaya koymaktadır.

Öte yandan, bu araştırma bazı sınırlılıklara da sahiptir. Araştırmanın uygun örnekleme yöntemiyle seçilen katılımcılardan oluşması bulguların genellenebilirliği açısından 
bir sınırlılıktır. Bu bakımdan farklı bölgelerden seçilecek katılımcılarla yapılacak çalışmalar ölçüm aracının geçerliği ve güvenirliğine dair daha güçlü destek sunabilir. Ayrıca, araştırmanın katılımcıları sadece üniversite öğrencilerinden oluştuğu için, uyarlaması gerçekleştirilen ölçeğin başka gruplarla da test edilmesi ölçeğin geçerliğinin ortaya konulması açısından faydalı olacaktır.

Ölçek puanlarının umut ve algılanan stres ile ilişkilerine yönelik sonuçlardan yola çıkarak araştırmacılara bazı önerilerde bulunulabilir. Ölçüm aracı kullanılarak bilişsel kontrol ve esnekliğin, iyimserlik, şükran duyma, azim, affedicilik, yapılandırmacı düşünme, psikolojik sağlamlık ve mutluluk gibi pozitif değişkenlerle ilişkisi araştırılabileceği gibi, umutsuzluk, kaygı, ruminasyon, öfke, saldırganlık gibi olumsuz değişkenlerle ilişkisi de incelenebilir. Sonuç olarak, bu araştırmanın stresli durumlarda bilişsel kontrol ve esneklik konusunda yapılacak araştırmalar için yol gösterici olarak alan yazına katkı sağlayacağı düşünülmektedir.

Finansal Destek: Yazar bu çalışma için finansal destek almamıştır.

\section{Kaynakça}

Al Jabari, R. M. (2012). Relationships among self-esteem, cognitive and psychological flexibility, and psychological symptomatology. (Yayımlanmamış Yüksek Lisans Tezi). University of North Texas, USA.

Alper, A. ve Deryakulu, D. (2008). Web ortamlı probleme dayalı öğrenmede bilişsel esneklik düzeyinin öğrenci başarısı ve tutumları üzerindeki etkisi. Eğitim ve Bilim, 33(148), 49-63.

Altunkol, F. (2011). Üniversite öğrencilerinin bilişsel esneklikleri ile algılanan stres düzeyleri arasındaki ilişkinin incelenmesi (Yayımlanmamış Yüksek Lisans Tezi). Çukurova Üniversitesi, Adana.

Badre, D. (2011). Defining an ontology of cognitive control requires attention to component interactions. Topics in Cognitive Science, 3(2), 217-221. https://10.1111/j.1756-8765.2011.01141.x.

Beck, A. T., Ward, C. H., Mendelson, M., Mock, J. ve Erbaugh, J. (1961). An inventory for measuring depression. Archives of General Psychiatry, 4(6), 561-571. https://dx.doi.org/10.1001/ archpsyc.1961.01710120031004

Bilgin, M. (2009). Developing a Cognitive Flexibility Scale: Validity and reliability studies. Social Behavior and Personality, 37(3), 343-353.

Büyüköztürk, Ş. (2011). Sosyal bilimler için veri analizi el kitabı: Ístatistik, araştırma deseni, SPSS uygulamaları ve yorum (14. bask1). Ankara: Pegem Akademi Yayınları.

Can, A. (2015). SPSS ile bilimsel araştırma sürecinde nicel veri analizi (5. baskı). Ankara: Pegem Akademi Yayınları.

Cardom, R. D. (2016). The mediating role of cognitive flexibility on the relationship between crossrace interactions and psychological well-being (Yayımlanmamış Doktora Tezi). University of Kentucky, USA.

Cartwright, K. B. (Ed.). (2008). Literacy processes: Cognitive flexibility in learning and teaching. New York: Guilford. 
Cohen, S., Kamarck, T. ve Mermelstein, R. (1983). A global measure of perceived stress. Journal of Health and Social Behavior, 24(4), 385-396.

Cohen, L., Manion, L. ve Morrison, K. (2007). Research methods in education. London: Routledge.

Coleman, D. (1993). Leisure based social support, leisure dispositions and health. Journal of Leisure Research, 25(4), 35-43. https://doi.org/10.1080/00222216.1993.11969933

Cousins, L. A., Tomlinson, R. M., Cohen, L. L. ve McMurtry, C. M. (2016). The power of optimism: Applying a positive psychology framework to pediatric pain. Pediatric Pain Letter, 18(1), 1-5.

Crowe, S. (1998). The differential contribution of mental tracking, cognitive flexibility, visual search, and motor speed to performance on Parts A and B of the Trail Making Test. Journal of Clinical Psychology, 54(5), 585-591.

Çelikkaleli, Ö. (2014). Bilişsel Esneklik Ölçeği'nin geçerlik ve güvenirliği. Eğitim ve Bilim, 39(176), 339-346. https://doi.org/10.15390/EB.2014.3466

Çokluk, Ö., Şekercioğlu, G. ve Büyüköztürk, Ş. (2010). Sosyal bilimler için çok değişkenli istatistik SPSS ve LISREL uygulamaları. Ankara: Pegem Akademi Yayınları.

De Dreu, C. K. W., Baas, M. ve Nijstad, B. A. (2008). Hedonic tone and activation in the moodcreativity link: Towards a dual pathway to creativity model. Journal of Personality and Social Psychology, 94(5), 739-756.

Dennis, J. P. ve Vander Wal, J. S. V. (2010). The Cognitive Flexibility Inventory: Instrument development and estimates of reliability and validity. Cognitive Therapy and Research, 34(3), 241-253. http:// dx.doi.org/10.1007/s10608-009-9276-4.

Doğan-Laçin, B. G. ve Yalçı, İ. (2018). Predictive roles of self-efficacy and coping strategies in cognitive flexibility among university students. Hacettepe University Journal of Education, 34(2), 358-371. https://doi.org/10.16986/HUJE.2018037424.

Fu, F. ve Chow, A. (2017). Traumatic exposure and psychological well-being: The moderating role of cognitive flexibility. Journal of Loss and Trauma, 22(1), 24-35. http://dx.doi.org/10.1080/153250 24.2016.1161428

Gabrys, R. L., Tabri, N., Anisman, H. ve Matheson, K. (2018). Cognitive control and flexibility in the context of stress and depressive symptoms: The Cognitive Control and Flexibility Questionnaire. Frontiers in Psychology, 9, 1-19. http://dx.doi.org/10.3389/fpsyg.2018.02219

Garcia-Garcia, M., Barceló, F., Clemente, I. ve Escera, C. (2010). The role of the dopamine transporter DAT1 genotype on the neural correlates of cognitive flexibility. The European Journal of Neuroscience, 31(4), 754-60. http://dx.doi.org/10.1111/j.1460-9568.2010.07102.x

Gläscher, J., Adolphs, R., Damasio, H., Bechara, A., Rudrauf, D., Calamia, M., Paul, L. K. ve Tranel, D. (2012). Lesion mapping of cognitive control and value-based decision making in the prefrontal cortex. Proceeding of the National Academy of Sciences, 109(36), 14681-14686. http://dx.doi. org/10.1073/pnas. 1206608109

Gurvis, J. ve Calarco, A. (2007). Adaptability: Responding effectively to change. USA: Center for Creative Leadership.

Gülüm, İ. V. ve Dăğ İ. (2012). The Turkish adaptation, validity and reliability study of The Repetitive Thinking Questionnaire and The Cognitive Flexibility Inventory. Anatolian Journal of Psychiatry, 13(3), 216-223.

Hambleton, R. K. (2005). Issues, designs, and technical guidelines for adapting tests into multiple languages and cultures. R. K. Hambleton, P. F. Merenda ve C. D. Spielberger (Ed.), Adapting educational and psychological tests for cross-cultural assessment içinde (s. 3-38). Mahwah, NJ: Lawrence Erlbaum Associates, Publishers. 
Hooper, D., Coughlan, J. ve Mullen, M. (2008). Structural equation modelling: Guidelines for determining model fit. Electronic Journal of Business Research Methods, 6(1), 53-60.

Hu, L. T. ve Bentler, P. M. (1998). Fit indices in covariance structure modeling: Sensitivity to underparameterized model misspecification. Psychological Methods, 3(4), 424-453.

Hu, L. T. ve Bentler, P. M. (1999). Cutoff criteria for fit indexes in covariance structure analysis: Conventional criteria versus new alternatives. Structural Equation Modeling, 6(1), 1-55. http:// dx.doi.org/10.1080/10705519909540118

Jacobson, M. J. ve Spiro, R. J. (1995) Hypertext learning environment, cognitive flexibility, and the transfer of knowledge: An empirical investigation. Journal of Educational Computing Research, 12(4), 301-333.

Johnco, C., Wuthrich, V. ve Rapee, R. M. (2014). The influence of cognitive flexibility on treatment outcome and cognitive restructuring skill acquisition during cognitive behavioural treatment for anxiety and depression in older adults: Results of a pilot study. Behaviour Research and Therapy, 57, 55-64. http://dx.doi.org/10.1016/j.brat.2014.04.005

Jöreskog, K. G. ve Sörbom, D. (1993). LISREL 8: Structural equation modeling with the SIMPLIS command language. Chicago: Scientific Software International.

Kato, T. (2012). Development of the Coping Flexibility Scale: Evidence for the coping flexibility hypothesis. Journal of Counseling Psychology, 14(4), 353-363. http://dx.doi.org/0.1037/a0027770

Kline, R. B. (2005). Methodology in the social sciences. Principles and practice of structural equation modeling (2. Bask1). New York: Guilford Press.

Koesten, J., Schrodt, P. ve Ford, D. J. (2009) Cognitive flexibility as a mediator of family communication environments and young adults' well-being. Health Communication, 24(1), 82-94. http://dx.doi. org/10.1080/10410230802607024

Koster, E. H., De Lissnyder, E., Derakshan, N., and De Raedt, R. (2011). Understanding depressive rumination from a cognitive science perspective: the impaired disengagement hypothesis. Clinical Psychology Review, 31, 138-145. http://dx.doi.org/10.1016/j.cpr.2010.08.005

Lazarus, R. ve Folkman, S. (1984). Stress, appraisal, and coping. New York: Springer.

Liao, A., Walker, R., Carmody, T. J., Cooper, C., Shaw, M. A., Grannemann, B. D., ... ve Trivedi, M. H. (2019). Anxiety and anhedonia in depression: Associations with neuroticism and cognitive control, Journal of Affective Disorders, 245, 1070-1078. https://doi.org/10.1016/j.jad.2018.11.072.

Mackie, M. A., Van Dam, N. T. ve Fan, J. (2013). Cognitive control and attentional functions. Brain and Cognition, 82(3), 301-312 http://dx.doi.org/10.1016/j.bandc.2013.05.004

Marsh, H. W., Balla, J. R. ve McDonald, R. P. (1988). Goodness-of-fit indexes in confirmatory factor analysis: The effect of sample size. Psychological Bulletin, 103(3), 391-410.

Marsh, H. W. ve Hau, K. T. (1996). Assessing goodness of fit: Is parsimony always desirable? The Journal of Experimental Education, 64(4), 364-390.

Martin, M. M. ve Rubin, R. B. (1995). A new measure of cognitive flexibility. Psychological Reports, 76(2), 623-626.

Morton, J. B., Ezekiel, F. ve Wilk, H. A. (2011). Cognitive control: easy to identify but hard to define. Topics in Cognitive Science, 3(2), 212-216. http://dx.doi.org/10.1111/j.1756-8765.2011. 01139.x

Oettingen G. ve Gollwitzer P. M. (2002) Turning hope thoughts into goal-directed behavior. Psychological Inquiry, 13, 304-7.

Robinson, M. J., Schmeichel, B. ve Inzlicht, M. (2010). A cognitive control perspective of self-control strength and its depletion. Social and Personality Psychology Compass, 4, 189-200 http://dx.doi. org/10.1111/j.1751-9004.2009.00244.x 
Schermelleh-Engel, K., Moosbrugger, H. ve Müller, H. (2003). Evaluating the fit of structural equation models: Tests of significance and descriptive goodness-of-fit measures. Methods of Psychological Research Online, 8(2), 23-74.

Schumacker, E. R. ve Lomax, G. R. (1996). A beginner's guide to structural equation modeling. Mahwah, NJ: Erlbaum.

Snyder, C. R., Harris, C., Anderson, J. R., Holleran, S. A., Irving, L. M., Sigmon, S. T., ... ve Harney, P. (1991). The will and ways: Development and validation of an individual-differences measure of hope. Journal of Personality and Social Psychology, 60, 570-585.

Snyder, C. R., Lopez, S. J., Shorey, H. S., Rand, K. L. ve Feldman, D. B. (2003). Hope theory, measurements, and applications to school psychology. Psychology Quarterly, 18, 122-139.

Spielberger, C.D., Gorsuch, R.C. ve Luschene, R. E. (1970). Manual for the State-Trait Anxiety Inventory. California: Consulting Psychologists Press.

Şencan, H. (2005). Sosyal ve davranışsal ölçümlerde güvenilirlik ve geçerlilik. Ankara: Pegem Akademi Yayıncilik.

Tabachnick, B. G. ve Fidell, L. S. (2013). Using multivariate statistics (6. Bask1). USA: Pearson Education Limited.

Tarhan, S. ve Bacanlı, H. (2015). Sürekli Umut Ölçeği'nin Türkçe'ye uyarlanması: Geçerlik ve güvenirlik çalışması. The Journal of Happiness and Well-being, 3(1), 1-14.

Tharp, J. ve Pickering, A. D. (2011). Individual differences in cognitive-flexibility: the influence of spontaneous eyeblink rate, trait psychoticism and working memory on attentional set-shifting. Brain and Cognition, 75, 119-125. http://dx.doi.10.1016/j.bandc.2010.10.010

Yerlikaya, E. E. ve İnanç, B. (2007, Ekim). Algılanan Stres Ölçeği'nin Türkçe çevirisinin psikometrik özellikleri (Psychometric properties of the Turkish translation of the Perceived Stress Scale). IX. Ulusal Psikolojik Danışma ve Rehberlik Kongresi'nde sunulan bildiri, Dokuz Eylül Üniversitesi, İzmir.

Zaehringer, J., Falquez, R., Schubert, A. L., Nees, F. ve Barnow, S. (2018). Neural correlates of reappraisal considering working memory capacity and cognitive flexibility. Brain Imaging and Behavior, 12(6), 1529-1543. http://dx.doi.org/10.1007/s11682-017-9788-6 


\section{Ek 1. Bilişsel Kontrol ve Esneklik Ölçeği}

\begin{tabular}{|c|c|c|c|c|c|c|}
\hline 1 & 2 & 3 & 4 & 5 & 6 \\
\hline $\begin{array}{c}\text { Hiç } \\
\text { katılmıorum }\end{array}$ & $\begin{array}{c}\text { Çoğunlukla } \\
\text { katılmıyorum }\end{array}$ & $\begin{array}{c}\text { Biraz } \\
\text { katılmıyorum }\end{array}$ & $\begin{array}{c}\text { Ne katılıorum } \\
\text { Ne } \\
\text { katılmıyorum }\end{array}$ & $\begin{array}{c}\text { Biraz } \\
\text { katılıyorum }\end{array}$ & $\begin{array}{c}\text { Çoğunlukla } \\
\text { katılıyorum }\end{array}$ \\
\hline
\end{tabular}

$\mathrm{Bu}$ ölçeğin amacı, stresli durumlar olumsuz düşünceleri ve duyguları tetiklediğinde genel olarak ne düşündüğünüzü / ne hissettiğinizi / ne yaptığınızı belirlemektir. Elbette, duruma bağlı olarak farklı davranabilirsiniz, ancak stresli ya da üzgün olduğunuzda genellikle ne düşündüğünüzü / hissettiğinizi / ne yaptığınızı düşünmeye çalışın. Aşă̆ıda yer alan ölçeği kullanarak, belirtilen ifadelere ne ölçüde katılıp katılmadığınızı belirtin.

Genellikle, stresli durumlarda...

\begin{tabular}{|l|c|c|c|c|c|c|c|}
\hline $\begin{array}{l}\text { 1. Nasıl bir adım atacağıma karar vermeden önce elimdeki } \\
\text { seçenekleri tartarım. }\end{array}$ & 1 & 2 & 3 & 4 & 5 & 6 & 7 \\
\hline $\begin{array}{l}\text { 2. Düşüncelerim ve duygularım üzerindeki kontrolümü } \\
\text { kaybediyormuşum gibi hissederim. }\end{array}$ & 1 & 2 & 3 & 4 & 5 & 6 & 7 \\
\hline 3. Duruma farklı bakış açıаrından yaklaşııım. & 1 & 2 & 3 & 4 & 5 & 6 & 7 \\
\hline $\begin{array}{l}\text { 4. Aniden ortaya çıkan düşüncelerden ve duygulardan kurtulmak } \\
\text { benim için zordur. }\end{array}$ & 1 & 2 & 3 & 4 & 5 & 6 & 7 \\
\hline $\begin{array}{l}\text { 5. Tepki vermeden önce çok yönlü bakış açısı ile durumu } \\
\text { değerlendiririm. }\end{array}$ & 1 & 2 & 3 & 4 & 5 & 6 & 7 \\
\hline $\begin{array}{l}\text { 6. Durumla en iyi şekilde başa çıkabilmek için harekete geçmeden } \\
\text { önce farklı çözüm yolları düşünmeye çalışıım. }\end{array}$ & 1 & 2 & 3 & 4 & 5 & 6 & 7 \\
\hline $\begin{array}{l}\text { 7. Hoş olmayan düşüncelerden veya duygulardan kurtulmak benim } \\
\text { için kolaydır. }\end{array}$ & 1 & 2 & 3 & 4 & 5 & 6 & 7 \\
\hline 8. Rahatsı edici düşünceleri görmezden gelmek benim için kolaydır. & 1 & 2 & 3 & 4 & 5 & 6 & 7 \\
\hline $\begin{array}{l}\text { 9. Nasıl bir tepki göstereceğime karar vermeden önce, kolaylıkla } \\
\text { farklı başa çıma stratejileri düşünebilirim. }\end{array}$ & 1 & 2 & 3 & 4 & 5 & 6 & 7 \\
\hline 10. Tepki vermeden önce olaylara farklı açlardan bakmaya çalışırım. & 1 & 2 & 3 & 4 & 5 & 6 & 7 \\
\hline $\begin{array}{l}\text { 11. Can sıkıcı düşünceler veya duygular yüzünden dikkatim } \\
\text { kolaylıkla dağılır. }\end{array}$ & 1 & 2 & 3 & 4 & 5 & 6 & 7 \\
\hline 12. Soruna birden fazla çözüm yolu bulmak için uğraşııım. & 1 & 2 & 3 & 4 & 5 & 6 & 7 \\
\hline $\begin{array}{l}\text { 13. Düşüncelerimi ve duygularımı, durumu içinde bulunduğu şartlara } \\
\text { göre değerlendirerek kontrol ederim. }\end{array}$ & 1 & 2 & 3 & 4 & 5 & 6 & 7 \\
\hline 14. Düşüncelerimi ve duygularımı kontrol altında tutabilirim. & 1 & 2 & 3 & 4 & 5 & 6 & 7 \\
\hline 15. Duygularımı yönetmede zorlanırım. & 1 & 2 & 3 & 4 & 5 & 6 & 7 \\
\hline 16. Düşüncelerim ve duygularım bir işe odaklanabilmemi engeller. & 1 & 2 & 3 & 4 & 5 & 6 & 7 \\
\hline $\begin{array}{l}\text { 17. Düşüncelerimi veya duygularımı, durumu yeniden } \\
\text { değerlendirerek yönetirim. }\end{array}$ & 1 & 2 & 3 & 4 & 5 & 6 & 7 \\
\hline $\begin{array}{l}\text { 18. Dikkatimi olumsuz düşüncelerden veya duygulardan başka yöne } \\
\text { çevirmekte zorlanırım. }\end{array}$ & 1 & 2 & 3 & 4 & 5 & 6 & 7 \\
\hline
\end{tabular}

Duygular Üzerinde Bilişsel Kontrol: 2, 4, 7, 8, 11, 14, 15, 16, 18

Değerlendirme ve Başa Çıkma Esnekliği: 1, 3, 5, 6, 9, 10, 12, 13, 17

Ters Maddeler: 2, 4, 11, 15, 16, 18 